\title{
Mobile Application and Web 2.0 as an E-Participation Mechanism: A Literature Analysis
}

\author{
https://doi.org/10.3991/ijim.v15i06.20673 \\ Halimah Abdul Manaf ( $\left.{ }^{\bowtie}\right)$, Mohamad Nur Salam Man \\ Universiti Utara Malaysia, Sintok, Malaysia \\ halimmanafabdegmail.com
}

\begin{abstract}
Every democratic government always in their goals in achieving inclusiveness in every decision-making process which will prevail in their efforts achieving the full principle of democracy, transparent, accountable, and good governance. Hence, e-participation has profoundly become one set of tools in bridging digital divide between people and their governments $(\mathrm{C} 2 \mathrm{G})$, governments and other government organisations (G2G), government and people (G2C), government and employees (G2E), and government and corporation (G2B) through the utilization advancement of information and communication technology (ICT). In regards to this, the mobile application and Web 2.0 system are often flagged for its potential in improving public participation which intended to improve the current lagging public services and to establish relationships between government and citizens based on virtual information sharing and public debate. Insight of this, does mobile application and Web 2.0 able to deliberately enhance e-participation in everydimension?
\end{abstract}

Keywords-E-Participation, mobile application, web 2.0, e-government, digital society

\section{$1 \quad$ Introduction}

It is undeniable that the booming in the ICT infrastructure in this century has created the next dimension of sophistication in the area in today's public administration field. The public sector has been called for the inclusion of advancement in innovation, driving service delivery towards a lot of personalised, outcome-driven, participative, efficient, and cooperative model [10]. Hence, the egovernment principle demanded comprehensive bottom-up or user-driven initiatives [11][7][2]. From this view, the public participation views on government are needed in the development of comprehensive national policy creation due citizen participation is the prominent benchmark on effective democratic good governance practices [3] [18] [15]. Thus, this paper seeks to dig out the literature on what the mobile application and Web 2.0 roles as a stimulant on the e-participation mechanism in shaping a digital society. 


\section{Roles of Web 2.0 As a Method of E-Participation Practices}

\subsection{Political purposes}

The ICT have been examined as a prudent and effective tool to strengthen the public participation in some occasion of the period, via e-Participation initiative, although it had combined achievement up to now in the political realm [4]. Web 2.0 generally can provide better accountability which becomes as one of the key modifications of future government [6] and the politician by deliberately providing an opportunity for public people to give some views, ideas and thought which can be improving the legitimacy and populism on some certain politicians [1]. In forward to this, [12] argues the distinction of Web 2.0 roles on the right-wing and left-wing ideologist parties. [14] has listed out some several example case of Web 2.0 as a fundamental tool mechanism in e-participation practices in EU:

- Politicians utilizing web 2.0 applications for more straightforward contact with the electorate. In numerous EU nations, government officials have writes and take an interest in person to person communication sites.

- Bringing peoples' cooperation upstream: Commentonthis.com permits residents to share their perspectives on the subtleties of key government archives, which have been part into passages to make them"commentable".

- Easy formation of weight bunches for explicit causes: change.org is where members can discover others keen on similar causes, and furthermore interface with lawmakers sharing their perspectives.

The below pictures are the example of the e-Petitions that have been initiated by the UK Government and Parliament:

Local to you

Find petitions being signed by people near you

UK postcode

\begin{tabular}{ll}
\hline & $a$
\end{tabular}

Start a petition

Anyone can start a petition as long as they are a British citizen or
UK resident

Start a petition

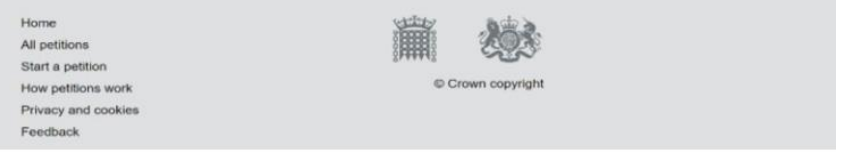

Fig. 1. Starting a petition by local residents 


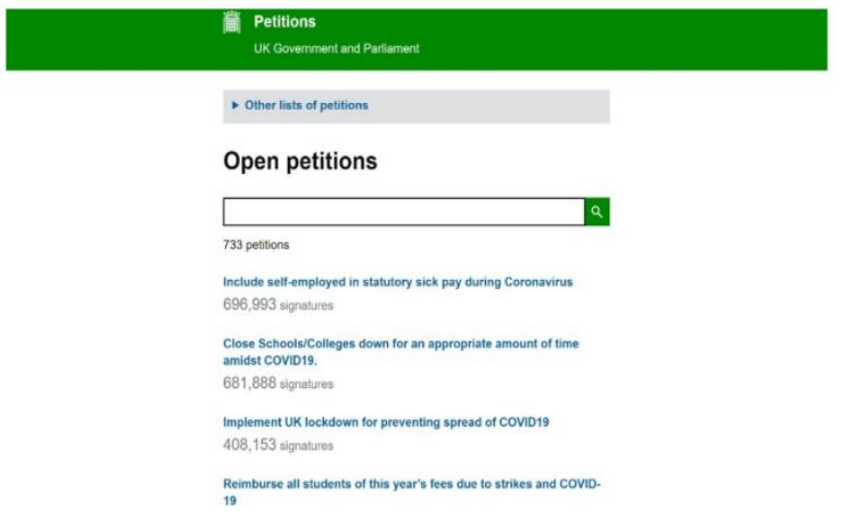

Fig. 2. Other Open e-Petitions that can be participate by local residents

\subsection{Law enforcement}

Law enforcement is a major key in the enhancing of government competence and efficiency. There is always a principle of law in every governmental management, that is; however, it depends on the level of supervision and coordination of the government in enforcing the existing legislation or not enforcing it. In a nutshell, it is back to the government initiative at the of the day. [14] again discussed a salient role of Web 2.0 from the perspective of law enforcement by the government from the example in Western countries that practices e- participation. There are, however, numerous approaches wherein web 2.0 may want to alternate the manner laws are enforced, together with a greater proactive function for citizens to take part [14]:

- Citizens can screen different residents, and openly disgrace them to implement the law. There are a few instances of this "little brother" marvel. Caughtya.org and mybikelane.org are sites where individuals post photographs of vehicles left on incapacitated leaving and bicycle paths, separately. This, obviously, raises issues of protection intrusion and over the top social control. Simultaneously, expanded social control can in the drawn-out lead to less requirement for checking by the administration.

- Citizens can share, screen and feature issues that worry them. A Chicago occupant made Chicagocrime.org, where open information on neighbourhood's wrongdoing are browsable by wrongdoing type and road, and geo-referenced utilizing Google Maps.

- Government can proactively search for resident' joint effort utilizing existing longrange informal communication. Police in Canada, the USA, and the UK have been utilizing YouTube to disperse video film, to recognize crooks got by reconnaissance cameras.

Once more, [14] presented some case that can be an example of Web 2.0 as a method of e-participationin NewYork, UnitedStates. With the creation of 
'Mybikelane.com' the site can enable the local city enforcement authorities to enforce the laws to violators that illegally parked their vehicle on the bike lanes. As for this, it will help the local city authority to effectively and efficiently enforcing the law via the collaboration of citizen initiative of e-participation. However, the site has been shut down by the owner in 2012 due to some circumstance. Still, this is one of another good example public e-participation initiative via Web 2.0 to ensure the local enforcement is on the run.

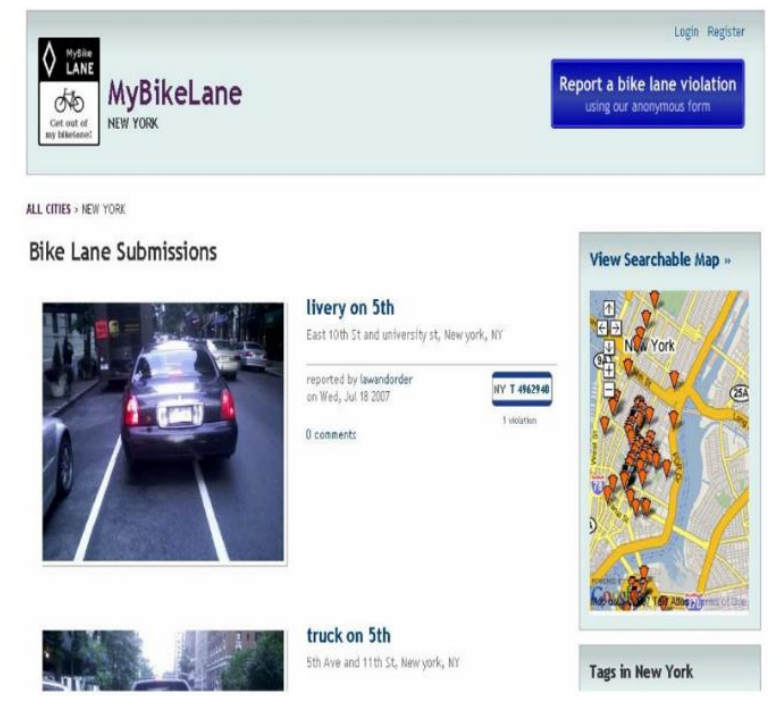

Fig. 3. Screenshot of mybikelane.com

In another example case in Malaysia, there is also an attempt on the creation of Web2.0 applications in some local government agencies in enforcing law in some certain areas of their coordination. For example, a local government agency such as City Council Omega developed a smart public access application which is so-called 'eAduan MBPP' apps to let the public to participate and report some issues in regards with the problems in the local communities. 'eAduan MBPP' is a few other initiative through the City Council of Omega to boom the wide selection of channels for lawsuits enforcement via a mobile device to enable the general public to make rapid, handy and effective lawsuits enforcement, appreciation, suggestion and any relatedenquiries immediately to the Council.

This app lets absolutely everyone who needs to make a complaint most effective needs to key in information of the complaint, place of the complaint (geotagging) and fasten the applicable photographs as evidence of the complaint to be despatched. The general public people additionally capable to check the status of their complaints through looking to view the movement taken by way of the Council at the complaints made [21]. 

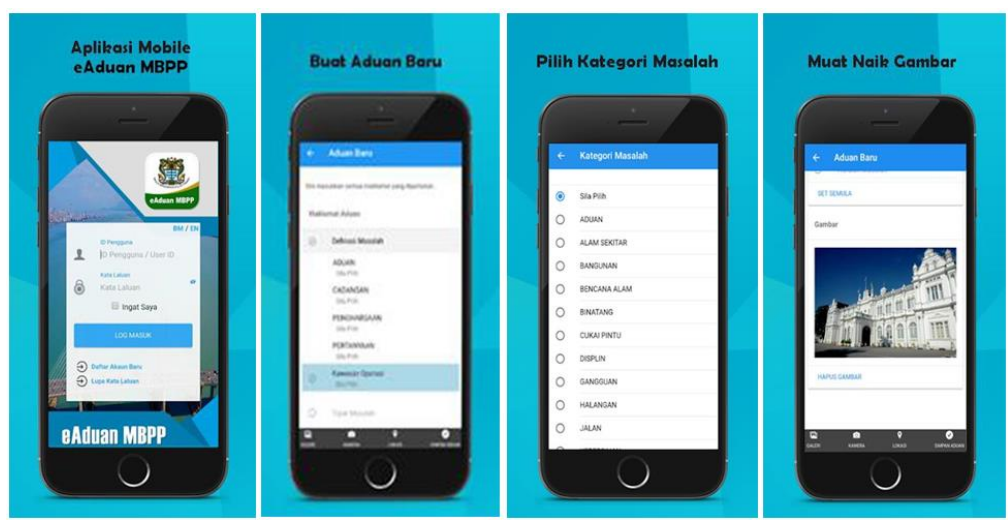

Fig. 4. A screenshot interface of eAduan

\subsection{Service provision}

[14] again provides a details explanation and example of service provision via Web 2.0 'local-public' e-participation initiative in providing comprehensive feedback and views on the current public or private service delivery provided by some certain organizations in the Western countries.

For instance, [14] once more provided an example of 'Patient Opinion' or 'Care Opinion' in the United Kingdom. The 'Patient Opinion' is a formerly name before being renamed as 'Care Opinion' today, is a non-earnings organisation provider that turned into released via a well-known Practitioner to enhance the United Kingdom national health service (NHS).

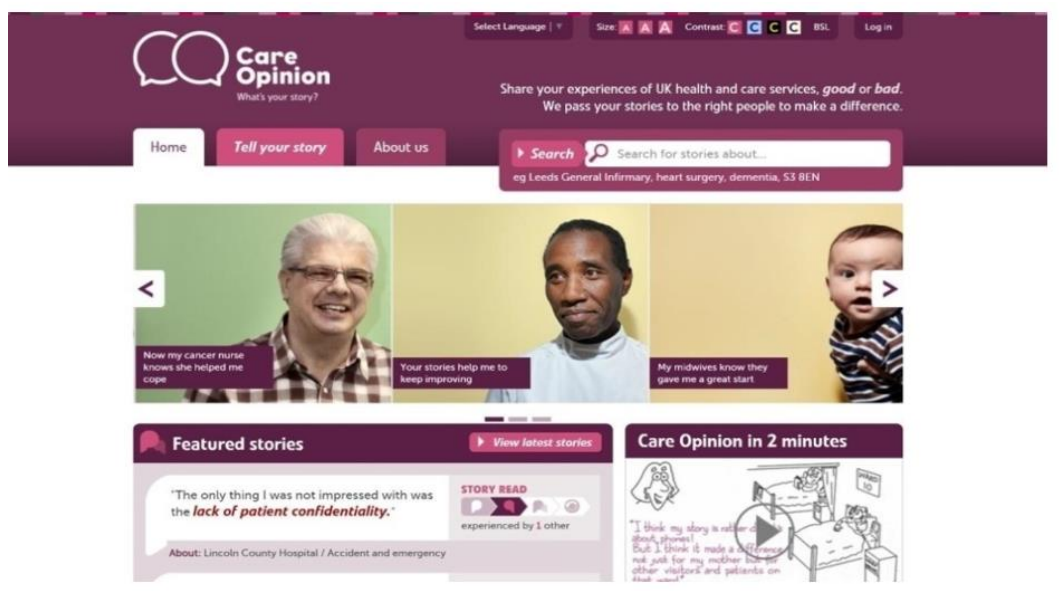

Fig. 5. A screenshot of Care Opinion website. 


\section{Conclusion}

Mobile application and Web 2.0 as another attempt on comprehensive public participation can be significantly leaving a good governance value on some particular nations that implementedit. This paper has been provided with some example and explanation of mobile application and Web 2.0 initiatives. This initiatives that might be able to enhance a better level of public participation through usage of mobile application and Web 2.0 technologies. However, in striving an effort of full force digital society requires the collaboration between the local society and government. One side of perspective would not aware what are their weakness, hence; that respective side must need another set of views that might aware of what is going wrong with their operations. Low level of public participation might be appropriate on some governmental organization in the short run, in the contrast of the long run; who knows what the perception that government organization might get on as they suffered from a huge loss in managing the public budget spending going on and wasting taxpayers money on some unnecessary program and policy.

\section{Acknowledgement}

The research was funded under Fundamental Research Grant Scheme, Malaysia (SO Code: 14185)

\section{$5 \quad$ References}

[1] Ahn, M. \& Bretschneider, S. (2011). Politics of E-Government: E-Government and the Political Control of Bureaucracy. Public Administration Review. 71: 414 - 424. https://doi.org/10.1111/j.1540-6210.2011.02225.x

[2] Alqaralleh, B., Al-Omari, A., \& Alksasbeh, M. (2020). An Integrated Conceptual Model for $\mathrm{m}$-Government Acceptance in Developing Countries: The Case Study of Jordan. International Journal Of Interactive Mobile Technologies (IJIM). 14(06): 115-136. https://doi.org/10.3991/ijim.v14i06.11449

[3] Barber, B. (1984). Strong Democracy: Participatory Politics for a New Age. Berkeley: University of California.

[4] Bryant, L. and Wilcox, D. (2007). Many-to-Many: Lessons from Web 2.0 for Participation and E-democracy. Post Party Politics,Involve.

[5] Frissen, V., van Staden, M., Huijboom, N., Kotterink, B., Huveneers, S., Kuipers, M., \& Bodea, G. (2008). Naar een 'User Generated State'? De impact van nieuwe media voor overheid en openbaar bestuur. TNO rapport. Retrieved from http://www.minbzk.nl/111201/naar-een-user https://doi.org/10.5553/tvh/1568654x2019019001005

[6] Frissen, V., J. Millard, et al. (2007). The future of eGovernment: An exploration of ICTdriven models of eGovernment for the EU in 2020. D. Osimo, D. Zinnbauer and A. Bianchi, Joint Research Centre. 
[7] Gauld, R., Goldfinch, S., \& Horsburgh, S. (2010). "Do They Want it? Do They Use it? The 'Demand-Side' of E-government in Australia and New Zealand”, Government Information Quarterly, 27: 177-186 https://doi.org/10.1016/j.giq.2009.12.002

[8] Goldfinch, S. (2007). Pessimism, Computer Failure, and Information Systems Development in the Public Sector. Public Administration Review. 67: 917-929. https://doi.org/10.1111/j.1540-6210.2007.00778.x

[9] ICEG (2008). 'Call for papers, workshops and tutorials', International Conference oneGovernment, Available online at: http://academicconferences.org/iceg/iceg2008/iceg08call-papers.htm

[10] International Development Association (IDA) (2011). Information and Communication Technology Agency of Sri Lanka (ICTA) Colombo, Sri Lanka. (3).

[11] Khan, G. F., Moon, J., Rhee, C., \& Rho, J. J. (2010). E-government Skills Identification and Development: Toward a Staged-Based User-Centric Approach for Developing Countries, Asia Pacific Journal of Information Systems. 20 (1): 1-31.

[12] Meijer A. (2012). The Do It Yourself State. The future of participatory democracy, Information Polity. 17(3-4): 303-314.

[13] Omar, A., Weerakkody, V. and Sivarajah, U. (2017). 'Digitally enabled service transformation in UK public sector: A case analysis of universal credit'. International Journal of Information Management, 37 (4): 350 - 356. https://doi.org/10.1016/ j.ijinfomgt.2017.04.001

[14] Osimo, D. (2008). Web 2.0 in government: Why and how. Institute for Prospectice Technological Studies (IPTS), JRC, European Commission, EUR, 23358.

[15] Teorell, J. (2006). Political participation and three theories of democracy: A research inventory and agenda. European Journal of Political Research. 4(2): 787-810. https://doi.org/10.1111/j.1475-6765.2006.00636.x

[16] United Nation (U.N.). (2016). United Nations Survey 2018: E-government in support of sustainable development. Retrieved from https://publicadministration.un.org/egovkb/enus/Reports/UN-EGovernment-Survey- 2016 https://doi.org/10.18356/2f33ae5a-en

[17] United Nations and American Society for Public Administration (2001). Benchmarking EGovernment: A Global Perspective. New York: United Nations Public Administration Network.

[18] Verba, S., Schlozman, K. L., and Brady, H. E. (1995). Voice and Equality. Harvard: Harvard University Press.

[19] YaNi., A. \& Bretschneider, S. (2007). Th e Decision to Contract Out: A Study of Contracting for E-Government Services in State Governments. Public Administration Review. 67: 531 - 544. https://doi.org/10.1111/j.1540-6210.2007.00735.x

[20] Zheng, Y. (2017). Explaining Citizens' E-Participation Usage: Functionality of EParticipation Applications. Administration \& Society. 49(3): 423-442. https://doi.org/10.1177/0095399715593313

[21] Zikri, M., Tarmiji, M., and Aziz, A. M. (2015). Local Government Service Efficiency: Public Participation Matters, International Journal of Social Science and Humanity. 5(10): 827-831. https://doi.org/10.7763/ijssh.2015.v5.565

\section{Authors}

Halimah Abdul Manaf is Associate Professor and Deputy Dean in the School of Government, Universiti Utara Malaysia. She obtained a $\mathrm{PhD}$ in the field of public management from the University of Hull, UK. Her areas of expertise are human 
resource management in public sector and local government. She is the executive board of the Asian Pacific Society for Public Affairs and the editorial board of several journals. Her works was published in some journals included International Journal of Public Administration, International Journal of Public Sector Management and Performance and Journal of Knowledge Management. Email: halimmanafabd@ gmail.com

Mohamad Nur Salam is a public management postgraduate student and Graduate Research Assistant from School of Government (SOG), College of Government, Law and International Studies (COLGIS), Universiti Utara Malaysia (UUM). Currently his primary thesis worked related to e-Participatation in the local government of Malaysia. Email: monsieur_salam@live.com

Article submitted 2020-12-21. Resubmitted 2021-02-09. Final acceptance 2021-02-13. Final version published as submitted by the authors. 